\title{
THE ETHICS OF OCCUPATIONAL HEALTH AND SAFETY IN TURKEY: RESPONSIBILITY AND CONSENT TO RISK
}

\author{
Fatih Artvinli ${ }^{1}$
}

\begin{abstract}
Work-related diseases, injuries, risks and deaths are the issues that have been recently gaining importance especially in developing countries. The ethical dimensions of occupational health and safety have remained as relatively understudied areas. Concepts such as responsibility, consent, autonomy, paternalism, choice, and certain values or justifications that are used in medical ethics and bioethics are also applicable to occupational health and safety. This article examines the ethical issues of responsibility and consent to occupational risk. It will first define the concepts of consent and risk, and then different views on responsibility and consent to risk will be discussed. The article will also examine the responsibility of the society and government regarding these concepts.
\end{abstract}

Key words: responsibility, consent, paternalism, autonomy, occupational health and safety

La ética de la salud ocupacional y temas de seguridad en Turquía: responsabilidad y consentimiento al riesgo

Resumen: Enfermedades relacionadas con el trabajo, lesiones, riesgos y muertes son temas de mayor importancia, especialmente en países en desarrollo. Las dimensiones éticas de la salud ocupacional y los temas de seguridad han sido relativamente menos examinados. La responsabilidad, el consentimiento, la autonomía, el paternalismo, la elección y otros conceptos, como valores y justificaciones usados en ética médica y bioética, son también aplicables al ámbito de la salud ocupacional y seguridad. Este artículo examina los temas éticos de responsabilidad y consentimiento relativos a riesgo ocupacional. En este artículo, primero, se definen los conceptos de consentimiento y riesgo, entonces se discuten puntos de vista diferentes sobre responsabilidad y consentimiento al riesgo y finalmente se examina la responsabilidad de la sociedad y el gobierno.

Palabras clave: responsabilidad, consentimiento, paternalismo, autonomía, salud ocupacional y seguridad

A ética da saúde e segurança ocupacionais na Turquia: responsabilidade e consentimento para o risco

Resumo: Doenças relacionadas com o trabalho, lesóes, riscos e mortes são temas que ganham importância, especialmente nos países em desenvolvimento. As dimensóes éticas de questões de saúde e segurança no trabalho têm sido relativamente pouco examinadas. Responsabilidade, consentimento, autonomia, paternalismo, escolha e outros conceitos, valores ou justificativas usadas em ética médica e bioética são também aplicáveis ao domínio da saúde e segurança ocupacionais. Este artigo examina as questóes de ética da responsabilidade e o consentimento ao risco ocupacional. Neste artigo, em primeiro lugar, os conceitos de consentimento e de risco são definidos; em seguida, diferentes pontos de vista sobre a responsabilidade e consentimento ao risco são discutidos e, finalmente, a responsabilidade da sociedade e do governo são examinados.

Palavras-chave: responsabilidade, consentimento, paternalismo, autonomia, saúde e segurança ocupacionais

\footnotetext{
${ }^{1}$ Acibadem University School of Medicine, Department of History of Medicine and Ethics, Acibadem University School of Medicine, Kayisdagi, Atasehir-Istanbul, Turkey

Correspondence: fatihartvinli@gmail.com.tr
} 


\section{Introduction}

Occupational health issues and work-related diseases, injuries and risks are becoming more visible and consequently they are also becoming the subjects of social, economic, and political debates in developing countries. Certain multinational companies have moved hazardous works to a number of different countries because of rapid globalization and the changing patterns of industrial production. Occupational diseases, chemical and biological hazards, and other physical dangers to workers have been widely studied by different disciplines ranging from economy to anthropology. Although occupational health is a public health issue, the ethical dimensions of occupational health and safety have largely remained unexamined. Work-related risks, injuries, diseases and deaths should be carefully examined in the developing countries where occupational health and safety regulations are not properly established or where there are no regulations present.

Turkey, as a rapidly developing country, has serious problems regarding occupational health and safety. According to the data compiled by the Worker's Health and Work Safety Assembly (WHSA), an independent labor organization, at least a number 1886 Turkish workers lost their lives at work in 2014. The major causes for death have been listed in the following way: falling, crushing and collapsing, electric shock, poisoning and suffocation, explosions and burning, cutting and amputating $(1,2)$. The debate with regard to occupational safety in Turkey has recently become an issue of much significance especially following the mine catastrophes of 2014, which killed 301 workers in Soma and 18 workers in Ermenek(2). These tragic accidents have clearly demonstrated that the existing laws and regulations regarding occupational health and safety in Turkey fall short of protecting the lives of the workers.

Workers are also often exposed to other occupational diseases and injuries. For instance, every year the number of workers that are exposed to silica, asbestos, carcinogens, toxins, and other hazardous chemicals or products and experience health risks related to these chemicals and products increase. The mining industry, for example, harbors dozens of biological, chemical, ergonomic, physical, and psychosocial hazards that range from noise to heat(3). Workers living in developed countries are usually protected from the physical hazards at work thanks to the existing occupational health and safety regulations(4). However, half of the working populations in the developing countries work within the framework of a poorly established or an absent occupational health and safety infrastructure. There are no major legislations, inspections, compensatory systems, occupational health services or health and safety training(5). The global expansion of precarious working model, outsourcing, and subcontracting both within and across countries also has an effect on the occupational health and safety environment(6).

The informal sector in Turkey is quite large and subcontracted work is a very common and established component of the economy. The poor working conditions especially in the mining, construction, and textile sectors lead to a number of occupational diseases. For example, thousands of workers are exposed to silica and as a result develop silicosis in textile industry. Over 70 former workers doing sandblasting dies from silicosis between 2007 and 2010(7-9). The studies that were conducted have revealed that these workers were young individuals, mostly male migrants from poor villages of Anatolia or immigrants from countries such as Azerbaijan, Georgia, Romania, Moldavia and Bulgaria who were, to a large extent, employed in workshops of global brands $(10,11)$.

Work-related risks, injuries, hazards and death are also experienced in the formal economy and regulated work environments. A variety of subjects could be discussed both in the developed and developing countries in terms of the ethical issues that the occupational health and safety present. The vulnerable position of the workers, migrant workers, child labor, right to work, right to health, discriminatory practices, inequality, confidentiality, and other such issues could be discussed on the grounds of ethics and ethical theories.

This paper will focus on the ethical issues regarding responsibility and individual consent to occupational risk. I will argue that responsibility and consent to risk pose serious ethical dilemmas 
in occupational health. I will examine different views on individual consent to occupational risk and then argue for the need to implement strict regulations with regard to occupational health and safety in Turkey.

\section{Responsibility and Consent}

Individual responsibility and consent are usually discussed in the medical context. Concepts such as consent, autonomy, paternalism, choice, and such values or justifications are also applicable to occupational health context. People take certain risks with regard to their health in their everyday lives, and they are often allowed to do this. For example, people smoke by their own choice and thus we assume that they are aware of the risks that the smoking contains. Can we compare this to voluntarily accepting to take up a risky job?

An individual's consent to the benefits and burdens of risk-taking are respected in the context of the medical services that are provided. We assume that individuals are rational and autonomous, and hence respect their decisions and consent. A key question at this point would be to ask whether individual consent to occupational risk is any similar to provide an informed consent in case of any treatment or medical risk.

I will start with the definitions of the basic concepts that are discussed here, namely consent and risk. Consent is generally used to refer to informed consent in the medical context. It indicates a process of communication between a patient and a physician that results in the patient's acceptance or refusal of a treatment or any other intervention. We justify certain actions in medical settings depending on the informed consent of the patient. In a non-technical context, the term risk refers to a situation in which it is likely that an undesirable event will take place(12). Risk can be defined as 'a possibility of injury, damage or loss' in an occupational context. Regarding the decisions on risk, two fundamentally different activities are significant: 1) measurement or estimation of risk, and 2) evaluation of its acceptability (13).

There are several essential elements for informed consent in the biomedical context. According to Beauchamp and Childress(14), informed consent depends on autonomy, which has several components: "We analyze autonomous action in terms of normal choosers who act (1) intentionally, (2) with understanding, and (3) without controlling influences that determine their actions". This means that a person is autonomous when he or she is able to act according to these three conditions, namely liberty, agency and understanding. If we consider the necessary conditions for informed consent regarding occupational risk, we can enumerate four basic criteria for individual consent to an occupational risk: 1) a worker should be competent to assess the risk 2) a worker should understand the risks 3) a worker should be fully informed about the risks that are involved in the work 4) finally a worker should voluntarily accept the risks.

I am of the opinion that we should problematize and contextualize the 'consent to risk' provided by an individual since the conditions underlying the consent affect our decisions.

If the consent to risk is given under pressure or forcefully, it is not acceptable in moral and legal terms. Individual consent by a worker to an occupational (workplace) risk presupposes that workers are fully informed with regard to the hazards and risks that they will face at the workplace. When we use the term voluntarily, we also would like to mean knowingly. The fact that a person voluntarily accepts occupational risk could also be taken to mean that s/he knowingly accepts the risk that is involved.

Norman Daniels gives an example from Ashford(15) to discuss consent to risk: workers using or working with chemical products face risks from toxins or carcinogens that are not visible in the same way that the risks from a collapsing building pose for a fireman or the smoke inhalation presents for a worker. These relatively visible risks are clear in the work environments; no special knowledge or information is required to raise the awareness of an individual working in one of those environments(16). A full consent requires that the relevant information or knowledge that are provided regarding the risks should be clear and workers should have access to full information about these risks. 
We can say that knowledge or information concerning a certain risk should have some conditions. For example, the time when a worker becomes aware of the relevant knowledge or information is crucial. Occupational risks may not be apparent or clear when the worker signs the contract. Some of the hazards or risks at a certain workplace could be invisible to the eye and occupational diseases may develop after several years of work in that particular workplace or even after leaving the work. In the case of the workers who sandblast denim products, the workers were not properly informed about the risks that were involved and the employer did not provide them with the required equipment (masks, devices etc.). The workers realized that they had developed silicosis for working under these conditions only after they quit their jobs due to the numerous symptoms of the disease. Although there is not a particular study that I could refer to, I could suggest that most of the workers in Turkey (especially in mining, textile, and construction sectors) are only partially informed with regard to the potential risks of the work. What happens generally is that workers learn the risks of the work when they start working. However, we still have one more question: What happens provided that the employer provides the worker with all the relevant information regarding the risks and the worker accepts to work under these conditions and gives consent to the risks?

Proponents of individual consent to risk argue that risk-taking and consent to risk are matters that should be left for the decision of the individual. Individuals could normally put their health at risk; they can lead an unhealthy life and we generally respect their decisions and choices when they happen to do that. However, we also know that people are responsible for their health. The problem arises when we question whether people are obliged to maintain a good health or not. According to Knowles(17) people have an obligation not only to themselves but also to others, to the citizens or taxpayers who bear the burden of the health expenditures. Emphasizing the importance of personal responsibility for health, Daniel Wikler(18) offers a division of responsibilities: "If we become sick or disabled as a result of neglecting to take care of ourselves, or by having taken undue risks, then dealing with these health needs should be seen as personal rather than social responsibilities and as such should not be considered on a par with other, unavoidable health needs".

Personal responsibility in occupational health and safety can be problematized in different contexts. Some argue that workers are (also) responsible for their health and the potential risks at work, whereas others argue for shared responsibility between employers and employees. When the issue concerns occupational safety and occupational accidents, certain people tend to blame workers themselves for 'behaving wrongly' at workplace. Behavior-based safety programs have been quite established in the occupational health and safety in the recent years. These programs direct their attention to the workers who might have an accident at the workplace rather than restructuring or redesigning the working environment, working conditions or the hazardous factors. These programs may even punish the workers and overlook the occupational hazards, which result in serious negative consequences in the long-term(19).

It is my opinion that individualized responsibility for matters involving occupational health and occupational risks leads to turning a blind eye to the social, economic, and political factors that are involved. This attitude could also render the responsibilities of the employers, society at large, and government invisible. Personal responsibility, decision-making processes, and consent constitute a complex interrelatedness in occupational health and safety. The proponents of individual consent to risk frame consent in terms of freedom and autonomy.

\section{Autonomy vs. Paternalism}

The moral significance of consent derives from the respect that is shown for individual autonomy. The autonomy here belongs to workers. Some people think that it is ethically acceptable to allow individuals to trade their health and safety in exchange of money. However, this sort of an argumentation is wrong, simply because it does not hold under certain conditions. Can we allow people to be cruelly tortured by someone in exchange for money or can we allow poor 
people to sell their organs to wealthy people? If we are to remember Kantian ethics, we should "treat people as an end, and never as a means to an end". In Kant's view, people cannot be tools or instruments. These examples illustrate that what we consider here is the dignity of human beings. By using the same reasoning, we can say that it is not acceptable for workers to trade their health and safety in exchange for money.

It can thereby be stated that consent alone is not adequate to guarantee the morality of an act. Consent is not adequate because various rights, duties, virtues, and agreements also determine the moral quality of an act(20). The proponents of consent to occupational risk argue that workers provide their consent in a completely free and voluntary manner. However, we should also take into consideration the power dynamics that are embedded in this very context for which consent is provided or a choice is made.

There is an asymmetric power relationship between the employer and the employee. Employers often focus on maximization of profits and production. Thus, they tend to consider health and safety-related issues as sources for further expenditures and cost, and regard the health of the workers as a secondary issue. The primary concern or consideration of the workers is generally the wages or the economic conditions that the work presents. When they negotiate the contract or the work with the employer, they often focus on economic conditions rather than health and safety issues. It goes without saying that the power relationship between the employer and the employee is not an equal one.

The primary responsibility of the employer should be to provide a safe and healthy work environment. Employers should cooperate with their workers and their representatives with regard to the occupational health and safety issues. Workers under particular conditions could be deemed personally responsible for their health-related behaviors at work and outside the work; however, they should not be held responsible for health problems arising from the work environments or the working conditions.
Proponents of individual consent to occupational risk argue that people may prefer or accept high wages for a risky job. This line of thinking indicates that if a person willingly chooses a risky job or occupational risk in order to make more money (in the form of higher wages), we should not interfere with his/her decision or choice. Economists also justify the risk at workplaces on the grounds of compensating wage differential (CWD). CWD, or hazard-pay, means that workers in risky jobs receive higher wages, in return for taking greater risk.

I think this line of thought regarding the workers' freedom or choices presents many problems. First of all, majority of the people are not able to select their job/work; most people work in a particular work environment due to a lack of alternative. If we are to talk about free choice, then he individual should have other reasonable alternatives that are available.

In discussing the Occupational Safety and Health Act of 1970 (OSHA) Regulation in terms of technological feasibility, Norman Daniels mentions consent, autonomy and paternalism in the context of occupational health and safety. Daniels argues that for a choice to be based on true consent and autonomy, real alternatives should be available(21). He also uses the term word of "quasi coercive" to describe restrictions on the individuals: "Let us call a proposal quasi-coercive if it imposes or depends on a restriction of someone's alternatives in a way that is unfair or unjust; that is, a just or fair social arrangement would involve a range of options for the individual both broader than and strongly preferred to the range in the proposal situation"(21). Gertrude Ezorsky uses the concept of "forcing offers" for Daniel's "quasi coercive proposals" (22).

My second objection to the traditional free choice approach revolves around the examination of the concepts of 'rationality' and 'rational decisionmaking' of the individuals. Workers may not be competent or rational in their risk-taking decisions especially for invisible and long-term risks. The psychological research, particularly on "bounded rationality", has illustrated that individuals are inconsistent and unreliable while making rational choices(23). 
The miners of Soma, whom I mentioned in the introduction, constitute a good example for the issues that are included in consent to risk and CWD. Mining is one of the occupations with the highest amount of risk and we know that it is generally the poor workers who are employed in this particularly risky line of work. Miners in Soma worked under unsafe and unhealthy conditions in return for very low wages. Besides, the miners were from the villages that are close to Soma and they usually had no alternative for work other than mining. They used to be farmers with little education.

Workers who have little education and who experience difficulty in recognizing subtle hazards often take up risky jobs. Hazardous works/jobs are not carried out by rational agents who are well informed about the risks that are involved(24). Less skilled and socially disadvantaged workers in Turkey, like in the rest of the world, typically carry out hazardous or risky occupations.

The freedom and autonomy of the workers should be respected and supported. I am of the opinion that their freedom to sign a contract that foresees risk in the work environment could be respected only if the workers also have the freedom to reject that contract and engage in other reasonable alternatives. Workers must not only be fully informed about risks and hazards; they must also have alternatives.

Objections to individual consent to occupational risk under certain conditions may be seen as "paternalism". Daniels discusses paternalism in the context of OHSA Regulations. He argues that stringent regulations involving occupational risks can threaten the liberty of workers and employers to make a contract through hazard pay. Stringent regulations seem "unduly paternalistic", perhaps valuing workers' health more highly than workers themselves value it(21). With respect to the possibility of paternalism and the importance of the protection of individual liberty, I believe that in the context of workplaces and working conditions, "individual liberty" is especially questionable in the developing world. Perhaps stringent regulations can be criticized on the grounds of "liberty" in a well-organized market or workplace (e.g., in which workers can change their work, and where there is availability of alternatives, as well as access to full information and contracts). However, this objection is not applicable to work environments in Turkey where regulations regarding occupational health and safety are in the process of emergence and the availability of alternatives is quite limited and the number of the unemployed young people is very high. Therefore, if we are concerned about the unequal power relations between employers and employees, this sort of "liberty" may give excessive power to employers at the expense of their employees.

Even in the presence of full information and fair consent, we sometimes call for a justifiable paternalism. I strongly believe that it is necessary to implement strict regulations in occupational health and safety in Turkey, and we must be concerned about workers' health more than the workers are concerned about their own health. In 2012, the Turkish Grand National Assembly adopted a new law on "Occupational Health and Safety (Law No: 6331)" from European legislation, which stipulates the right for fair work conditions, and the right to health and safety at work. The OHS Law of Turkey puts forward the standards in dealing with toxic, chemical, or any other harmful materials and products in the workplace. It also requires that certain practices or tools in the workplace, such as masks, cameras, and devices that measure hazards or exposure levels, exist. The OHS Law and the Risk Assessment Regulation underline the importance of taking security measures to eliminate or decrease potential risks at workplaces. Even though progressive and essential legislation that aim to prevent work-related accidents, fatal injuries, and deaths has been on the rise in the recent years, the obligations that are imposed by the Law are not adequately inspected.

\section{Conclusion}

Occupational health and safety issues are becoming more visible in developing countries. The type and the structure of the economy, unemployment, absence of regulations and codes in occupational health and safety or absence of implementations and control can be listed as the main reasons for the high number of work-related diseases, injuries, risks and deaths in developing 
countries. Employers often focus on maximization of profits and production; therefore, the health of the workers becomes a secondary issue for them. Workers with no other available alternative accept the risky jobs and they generally focus on the economic conditions presented by the job rather than considering the health and safetyrelated issues.

Proponents of individual consent to occupational risk argue that people may prefer or accept high wages for a risky job. The freedom and autonomy of the workers should be supported provided that the workers also have the freedom to reject a work contract and have other reasonable alternatives. Objections to individual consent to occupational risk under certain conditions may be seen as "paternalism". Even in the presence of full information and fair consent, we sometimes call for a justifiable paternalism.
In conclusion, it should be emphasized that individual consent to risk does not take away responsibility from society. Society should act so as to enhance the unsafe working conditions and occupational risks. Society has a moral obligation to take measures for reducing workers' exposure to occupational risks and hazards, and for providing the workers with more information about these issues. Majority of the debates in public health policy have focused on society's obligation to provide access to health care. Society is also responsible, however, not only for the health of its members, but also for occupational health and risks. Non-governmental institutions can have a significant role in occupational health and safety by offering certifications of particular occupational health and safety measures for employers. Finally, the government is the main responsible body to ensure the safety and health of the workers. It implements the law strictly and conducts regular inspections in the fields.

\section{Acknowledgement}

This work was supported by the Fogarty International Center/National Institutes of Health (NIH) grant (5R25TW009248, KM Munir, PD/ PI) Boston Children's Hospital, Division of Developmental Medicine, Harvard Medical School. 
The ethics of occupational health and safety in Turkey: responsibility and consent to risk - Fatih Artvinli

\section{References}

1. Worker's Health and Work Safety Assembly (WHSA). Report of 2014. Access: January 10, 2016. Available at: http:// www.guvenlicalisma.org/index.php?option $=$ com_content \&view=article\&id=12861: this-is-what-akp-governmentcalls-new-turkey-at-least-1886-workers-died-in-2014\&catid=149:is-cinayetleri-raporlari\&Itemid=236

2. Today's Zaman (Daily Newspaper). 361 miners killed in 2014 in job-related accidents. 6 January 2015. Access: January 15, 2016. Available at: http://www.todayszaman.com/anasayfa_361-miners-killed-in-2014-in-job-related-accidents_369028.html

3. Donoghue AM. Occupational health hazards in mining: an overview. Occupational Medicine 2004; 54(5): $283-289$.

4. Burgard AS, Lin KY. Bad jobs, bad health? How work and working conditions contribute to health disparities. American Behavioral Scientist 2013; 57(8): 1105-1127.

5. London L, Kisting S. Ethical concerns in international occupational health and safety. Occupational Medicine 2002; 17(4): 587-600.

6. Quinlan M, Mayhew C, Bohle P. The global expansion of precarious employment, work disorganization, and consequences for occupational health: A review of recent research. International Journal of Health Services 2001; 31(2): 335-414.

7. Kilicaslan Z. Dying of silicosis today. In Cappuccio S, Toti M, (eds.) Jeans to Die For-From Genoa to Istanbul: Sandblasting Jeans in Turkey. Roma: Ediesse; 2010: 201-207.

8. Yasin Y. Civil remedy to a political disease. In Cappuccio S, Toti M, (eds.) Jeans to Die For-From Genoa to Istanbul: Sandblasting Jeans in Turkey. Roma: Ediesse; 2010: 159-67.

9. Akgun M, Araz O, Akkurt I, Eroglu A, Alper F, et al. An epidemic of silicosis among former denim sandblasters. European Respiratory Journal 2008; 32(5): 1295-303.

10. Cappuccio S. The human cost of a fashion icon. HesaMag 2009; 1: 46-47.

11. Bayram H, Ghio AJ. Killer Jeans and Silicosis. American Journal of Respiratory and Critical Medicine 2011; $184: 1322-$ 1324.

12. Hansson, Sven Ove. Risk. In The Stanford Encyclopedia of Philosophy. Edward N. Zalta (ed.). 2014 Edition. Available at http://plato.stanford.edu/archives/spr2014/entries/risk/

13. Gibson M. Risk. In Encylopedia of Ethics. Lawrence C. Becker, Charlotte B. Becker (ed.). New York and London: Routledge; 2001: 1513-1515.

14. Beauchamp TL, Childress JF. Principles of Biomedical Ethics. 6th ed. Oxford: Oxford University Press; 2008.

15. Ashford N. Crisis in the Workplace: Occupational Disease and Injury, Cambridge, MA: MIT Press; 1976.

16. Daniels N. Consent to Workplace Risk and Health Protection. In Just Health: Meeting Health Needs Fairly. Cambridge; New York: Cambridge University Press; 2008.

17. Knowles JH. The responsibility of the individual. Daedalus 1977; 106(1): 57-80.

18. Wikler D. Personal and social responsibility for health. In Anand S, Peter F, Sen A, (eds.) Public Health, Ethics, and Equity. Oxford: Oxford University Press; 2005: 107-133.

19. Quinn MM. Occupational health, public health, worker health. American Journal of Public Health 2003; $93(4): 526$.

20. Frechette KS. Trading jobs for health: Ionizing radiation, occupational ethics, and the welfare argument. Science and Engineering Ethics 2002; 8(2): 139-154.

21. Daniels N. Doth OSHA protect too much? In Just Health Care. Cambridge: Cambridge University Press; 1985: 140179.

22. Ezorsky G. Freedom in the Workplace? Ithaca: Cornell University Press; 2007.

23. Tversky A, Kahneman D. Rational Choice and the Framing of Decisions. Journal of Business 1986; 59: 251-278.

24. Shrader K. Environmental Justice: Creating Equity, Reclaiming Democracy. Oxford University Press; 2002.

Received: February 2, 2016

Accepted: February 11, 2016 